\title{
Interleukin-18 in Human Milk
}

\author{
YASUSHI TAKAHATA, HIDETOSHI TAKADA, AKIHIKO NOMURA, KOICHI OHSHIMA, \\ HIDEKI NAKAYAMA, TOMOTERU TSUDA, HITOO NAKANO, AND TOSHIRO HARA
}

\author{
Departments of Pediatrics [Y.T., H.T., A.N., H. Nakayama, T.H.] and Gynecology and Obstetrics [H. \\ Nakano], Graduate School of Medical Sciences, Kyushu University, Fukuoka, Japan; First Department of \\ Pathology, School of Medicine, Fukuoka University, Fukuoka, Japan [K.O.]; Department of Gynecology \\ and Obstetrics Fukuoka City Hospital, Fukuoka, Japan [T.T.]
}

\begin{abstract}
We analyzed IL-18 levels of human milk. Colostrum contained significantly higher levels of IL-18 compared with early milk and mature milk. By stepwise multiple linear regression analysis, preterm delivery and pregnancy complications of mothers significantly correlated with high levels of IL-18 in human milk ( $p=0.0007$ and 0.0018 , respectively). There was a significant correlation between the levels of IL-18 and soluble Fas ligand in colostrum $(p=0.0003)$. IL-18 was detected in actively secreting epithelial cells in lactating mammary gland by immunohistochemical staining. These results suggest that IL-18 in colostrum plays an important role in host defense of high-risk neonates. (Pediatr Res 50: 268-272, 2001)
\end{abstract}

\section{ABSTRACT}

\author{
Abbreviations: \\ TNF- $\boldsymbol{\alpha}$, tumor necrosis factor-alpha \\ sFasL, soluble Fas ligand \\ IFN- $\boldsymbol{\gamma}$, interferon-gamma \\ TGF- $\boldsymbol{\beta}$, transforming growth factor-beta \\ GAPDH, glyceraldehyde 3-phophate dehydrogenase \\ Th1, T helper type 1 \\ Th2, T helper type 2
}

IL-18 is produced by activated macrophages (1), keratinocytes (2), and intestinal epithelial cells (3). IL-18 mediates inflammatory response by inducing the production of chemokines, granulocyte-macrophage colony-stimulating factor, IL-2, and TNF- $\alpha$ by mononuclear cells (4). IL-18 strongly induces IFN- $\gamma$ and TNF- $\alpha$ production by $\mathrm{T}$ and natural killer (NK) cells when costimulated with IL-12, IL-2, mitogen, or microbial agents $(4,5)$. It also induces Fas ligand (FasL) expression on lymphocytes (6) and enhances their capacity to mediate cytotoxicity against Fas-expressing cells, which may play an important role in the clearance of infected cells (7).

Human milk contains a multitude of enzymes, hormones, growth factors, and immunologic agents (8). Among them, various cytokines, including IL-1 $\beta$ (9), IL-6 (10), IL-12 (11), TNF- $\alpha$ (12), IFN- $\gamma$ (13), IL-8 (14), IL-10 (15), TGF- $\beta$ (16), and $\mathrm{sFasL}$ (17), may provide both adaptive and innate immune responses in host defense against enteric or respiratory pathogens $(18-20)$.

In this study, we measured IL-18 levels along with other cytokines in human milk from mothers with or without preterm

Received April 4, 2000; accepted March 2, 2001.

Correspondence and reprint requests: Hidetoshi Takada, M.D., Ph.D., Department of Pediatrics, Graduate School of Medical Sciences, Kyushu University, 3-1-1, Maidashi, Higashi-ku, Fukuoka 812-8582, Japan; e-mail: harat@pediatr.med.kyushu-u.ac.jp

Supported, in part, by Grant-in-Aid for Encouragement of Young Scientists (H.T), and a grant from the Morinaga Houshikai. delivery or pregnancy complications. We found that colostrum from mothers with preterm delivery or pregnancy complications contained significantly higher concentrations of IL-18. The significance of IL-18 in human milk, especially for highrisk neonates, is discussed.

\section{MATERIALS AND METHODS}

Milk sample collection. Colostrum (within first $72 \mathrm{~h}$ postpartum), early milk (between $72 \mathrm{~h}$ to $7 \mathrm{~d}$ postpartum), and mature milk ( 1 mo after the delivery) were collected in the maternity and perinatal care units of Kyushu University Hospital and Fukuoka City Hospital. Table 1 summarizes the characteristics of milk sample donors. All mothers received verbal and written information about the aim of this study. Informed consent was obtained from each mother. Milk samples were collected in sterile polypropylene tubes by the mothers with manual breast pumps at the hospital. They were immediately processed. After removal of lipids, they were stored in $1.5-\mathrm{mL}$ polypropylene tubes at $-80^{\circ} \mathrm{C}$. Cellular components were washed twice with $\mathrm{PBS}$ and stored at $-80^{\circ} \mathrm{C}$ in sterile polypropylene tubes until use.

Purification of peripheral blood monocytes. Heparinized blood samples were obtained from four healthy volunteers. Informed consent was obtained from each donor. After mononuclear cells were obtained by density-gradient centrifugation 
Table 1. Characteristics of milk donors

\begin{tabular}{lccc}
\hline & $\begin{array}{c}\text { Preterm delivery } \\
(n=45)\end{array}$ & $\begin{array}{c}\text { Term delivery } \\
(n=71)\end{array}$ & $\begin{array}{c}\text { Total } \\
(n=116)\end{array}$ \\
\hline No pregnancy complications & 5 & 68 & 73 \\
Pregnancy complications & $40^{*}$ & 3 & 43 \\
PROM & 17 & 1 & 18 \\
Chorioamnionitis & 12 & 0 & 12 \\
Threatened premature delivery & 26 & 0 & 26 \\
Abruptio placentae & 3 & 0 & 3 \\
Toxemia of pregnancy & 8 & 2 & 10 \\
Other infectious complications & 0 & 0 & 0 \\
Cesarean section & 23 & 6 & 29 \\
\hline
\end{tabular}

* Twenty of 40 mothers had more than one pregnancy complications. In 20 mothers who had more than one pregnancy complications, 7 had three pregnancy complications (PROM [premature rupture of membrane], threatened premature delivery and chorioamnionitis). Thirteen had two pregnancy complications (5 had PROM and threatened premature delivery, 4 had toxemia of pregnancy and threatened premature delivery or abruptio placentae, 3 had PROM and chorioamnionitis or toxemia of pregnancy, and 1 had threatened premature delivery and chorioamnionitis).

using Ficoll-Hypaque (Pharmacia, Piscataway, NJ, U.S.A.), $\mathrm{CD}_{14}{ }^{+}$monocytes were enriched by cell sorting using EPICS ALTRA (Beckman-Coulter, Hialeah, FL, U.S.A.). The purity of $\mathrm{CD}_{14}{ }^{+}$cells was almost $99 \%$.

Cytokine assays. We measured the cytokine levels of colostrum and serum with ELISA kits according to the manufacturers' instructions (IL-18 and sFasL from MBL, Nagoya, Japan; IL-12, IFN- $\gamma$, and TNF- $\alpha$ from Amersham Pharmacia Biotech, Uppsala, Sweden). With respect to IL-18 assay, we used an ELISA kit that detects the biologically active form but not the biologically inactive form of IL-18 (21). The minimum detectable levels of each cytokine were $12.5 \mathrm{pg} / \mathrm{mL}, 3 \mathrm{pg} / \mathrm{mL}$, $2 \mathrm{pg} / \mathrm{mL}, 5 \mathrm{pg} / \mathrm{mL}$, and $0.1 \mathrm{ng} / \mathrm{mL}$ for IL-18, IL-12, IFN- $\gamma$, TNF- $\alpha$, and sFasL, respectively. To analyze the effects of other properties of human milk on the quantification of IL-18 levels by ELISA, we performed recovery tests by measuring IL-18 levels in 10 milk samples with or without adding specific amounts of recombinant human IL-18. The ratios of the measured and calculated concentrations were $93.3 \pm 12.7 \%$ (mean \pm SD). We found that milk components did not greatly influence the quantification of IL-18.

Detection of IL-18 mRNA in cellular components of human milk. As milk cells contained sufficient proportions of monocytes (40-65\% in seven milk samples), IL-18 mRNA expression levels of milk cells were compared with those of purified peripheral blood monocytes. Total RNA was isolated from seven milk cell samples and four peripheral blood CD14 ${ }^{+}$ cells using a nucleic acid purification system, MagExtractor MFX-2000 (Toyobo Co., Ltd., Osaka, Japan). Reverse transcription (RT) of RNA was performed by using a first-strand cDNA synthesis kit (Amersham Pharmacia Biotech). IL-18 mRNA levels were compared among each sample by semiquantitative RT-PCR by setting the same levels of GAPDH mRNA expression. The primer pair for GAPDH was 5'-GAAGGTGAAGGTCGGAGTC-3' and 5'-GAAGATGGTGATGGGATTTC-3'. The primer pair for IL-18 was 5'-GCTT GAATCTAAATTATCAGTC-3' and 5'-GAAGATTCAAATTGCATCTTAT-3'. PCR was performed at $94^{\circ} \mathrm{C}$ for $5 \mathrm{~min}$, followed by 40 cycles at $94^{\circ} \mathrm{C}$ for $30 \mathrm{~s}, 60^{\circ} \mathrm{C}$ for $30 \mathrm{~s}$, and $72^{\circ} \mathrm{C}$
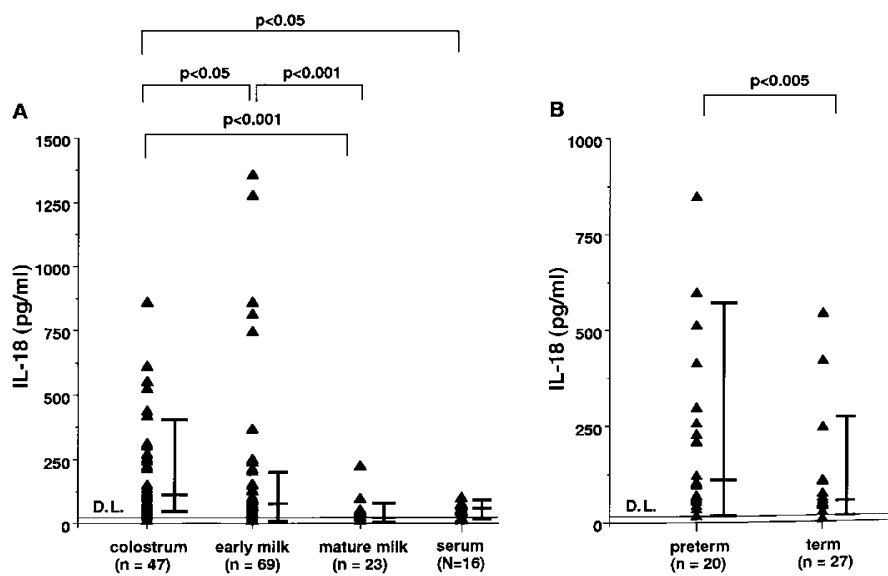

Figure 1. IL-18 levels of human milk. (A) IL-18 levels of colostrum, early milk, mature milk, and serum of lactating mothers. (B) IL-18 levels of colostrum from mothers with preterm and term delivery. Each bar represents median with a range from 10 th percentile to 90 th percentile. D.L., detection limit of IL-18.

for $30 \mathrm{~s}$, with a final extension for $5 \mathrm{~min}$ at $72^{\circ} \mathrm{C}$ with a Takara PCR Thermal Cycler PERSONAL (Takara, Otsu, Japan).

Immunohistochemical staining of IL-18. Lactating $(n=7)$ and nonlactating $(n=2)$ mammary gland specimens were obtained from nine patients aged 20-29 y with breast tumors (fibroadenoma, fibrocystic disease). Informed consent was obtained from each mother. The paraffin-embedded samples, fixed in buffered formalin, were used. After deparaffinization, each specimen was first incubated for 5 min with 3\% hydrogen peroxide, followed by a 5-min incubation with blocking serum. The specimen was then incubated with anti-IL-18 MAb (clone 25-2G, mouse IgG1, MBL, Nagoya, Japan) or control antibody for $10 \mathrm{~min}$. Each incubation was followed by a wash with PBS. The specimen was incubated with biotinylated second antibody for $10 \mathrm{~min}$ and with peroxidase-labeled streptavidin for $10 \mathrm{~min}$. Staining was completed after a 10-min incubation with $3 \%$ 3-amimo-9-ethylcarbazole.

Statistical analysis. Kruskal-Wallis test and multiple comparison (Bonferroni method) were used to compare IL-18 levels among each group and Mann-Whitney U test was used to compare between two groups (colostrum and maternal serum, and colostrum from mother with term or preterm delivery). Stepwise multiple linear regression analysis was performed to analyze factors that influenced IL-18 levels (22). The correlation between the maternal events of pregnancy complications and premature delivery was analyzed by $\chi^{2}$ test.

Ethics. This study was approved by the Regional Ethics of Committee for Human Research at the Faculty of Medicine of Kyushu University.

\section{RESULTS}

IL-18 levels of human milk. We analyzed IL-18 levels of human milk from mothers with preterm and term delivery by ELISA, which detects the biologically active form of IL-18. Forty-three of 47 samples (91\%) in colostrum, 56 of 69 samples $(81 \%)$ in early milk, and 11 of 23 samples $(48 \%)$ in mature milk were beyond the detection limit by ELISA for 
Table 2. Factors influencing IL-18 concentration in colostrum (stepwise multiple linear regression analysis)

\begin{tabular}{|c|c|c|c|c|}
\hline Variable & Coefficient & SE & $F$ Value & $p$ Value \\
\hline \multicolumn{5}{|l|}{ Analysis A $(n=116)^{*}$} \\
\hline Preterm delivery & 0.51 & 0.1463 & 12.29 & 0.0007 \\
\hline \multicolumn{5}{|l|}{ Analysis B $(n=116) \dagger$} \\
\hline
\end{tabular}

* Preterm delivery, each pregnancy complication (toxemia of pregnancy, chorioamnionitis, threatened premature delivery, abruptio placentae, and premature rupture of membrane) and cesarean section were included as variables in analysis A.

$\dagger$ Gestational weeks at delivery, pregnancy complications, and cesarean section were included as variables in analysis B.

IL-18. Colostrum contained significantly higher levels of IL-18 compared with early milk (Bonferroni method, $p<0.05$ ) or mature milk (Bonferroni method, $p<0.001$ ) (Fig. 1A). In addition, colostrum contained higher levels of IL-18 compared with maternal serum (Mann-Whitney $\mathrm{U}$ test, $p<0.05$ ). Colostrum from mothers with preterm delivery contained significantly higher levels of IL-18 compared with those with delivery at term (Mann-Whitney $\mathrm{U}$ test, $p<0.005$ ) (Fig. $1 B$ ). There were no correlations between colostrum and serum IL-18 levels from same mothers (data not shown).

We performed stepwise multiple linear regression analysis to further access the factors that contribute to the high levels of IL-18 in colostrum. As shown in Analysis A of Table 2, when preterm delivery and pregnancy complications (toxemia of pregnancy, threatened premature delivery, abruptio placentae, chorioamnionitis, and premature rupture of membrane) and cesarean section were included as variables, preterm delivery was significantly associated with high levels of IL-18. On the other hand, when gestational weeks at delivery were included as variables in addition to the pregnancy complications and cesarean section (Analysis B of Table 2), high levels of IL-18 were significantly associated with pregnancy complications but not with gestational weeks of delivery, although each pregnancy complication by itself did not significantly affected the levels of IL-18 (data not shown). A $\chi^{2}$ test revealed that pregnancy complications and preterm delivery were significantly associated $(p<0.0001$, data not shown). These results suggested that high levels of IL-18 were associated with preterm delivery, which was closely associated with pregnancy complications.

$I L-18, I F N-\gamma, T N F-\alpha, I L-12$, and $s F a s L$ concentrations in colostrum. As shown in Figure 2, colostrum contained TNF- $\alpha$, IL-12, IFN- $\gamma$, and sFasL, as reported previously $(10,11)$. TNF- $\alpha$ levels in colostrum were higher in mothers with preterm delivery than in those with delivery at term, whereas IL-12, IFN- $\gamma$, and sFasL levels showed no significant differences between those with preterm and term delivery. Then, we analyzed associations between each cytokine and IL-18 in colostrum. By stepwise multiple linear regression analysis, we found that only sFasL was significantly correlated with high concentration of IL-18 in colostrum (coefficient: 1.155 , SE: $0.3042, F$ value: $14.41, p=$ $0.0003)$.

Semiquantitative PCR analysis of IL-18 mRNA from cellular components of colostrum. As milk cells contained sufficient proportions of monocytes $(40-65 \%$ in seven milk samples), IL-18 mRNA levels of cellular components in colostrum were examined in seven samples and compared

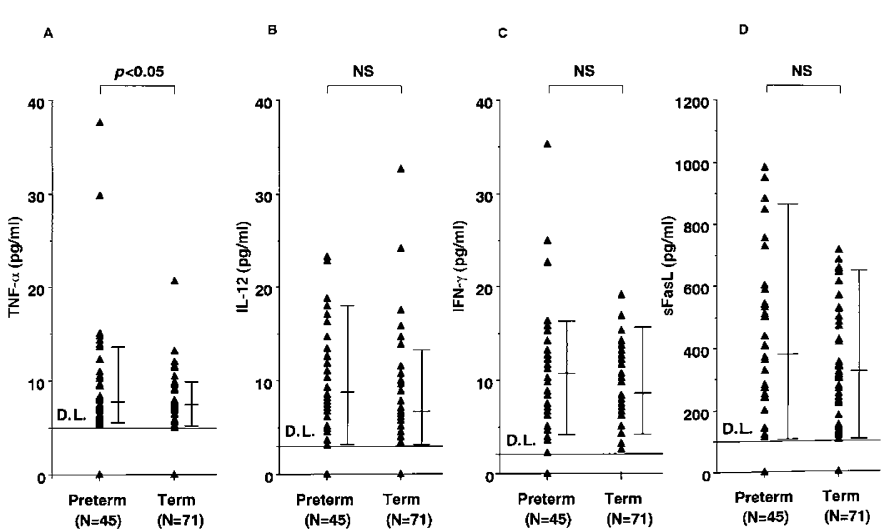

Figure 2. TNF- $\alpha(A), \operatorname{IL}-12(B), \operatorname{IFN}-\gamma(C)$, and sFasL $(D)$ levels in colostrum from mothers with preterm and term delivery. Each bar represents median with a range from 10th percentile to 90th percentile. Colostrum samples from mothers with preterm delivery and term delivery were positive (beyond the detection limit by ELISA) for TNF- $\alpha$ in $97 \%$ and $77 \%$, for IL- 12 in $91 \%$ and $86 \%$, for IFN- $\gamma$ in $97 \%$ and $100 \%$, and for sFasL in $94 \%$ and $95 \%$, respectively. D.L., detection limit.

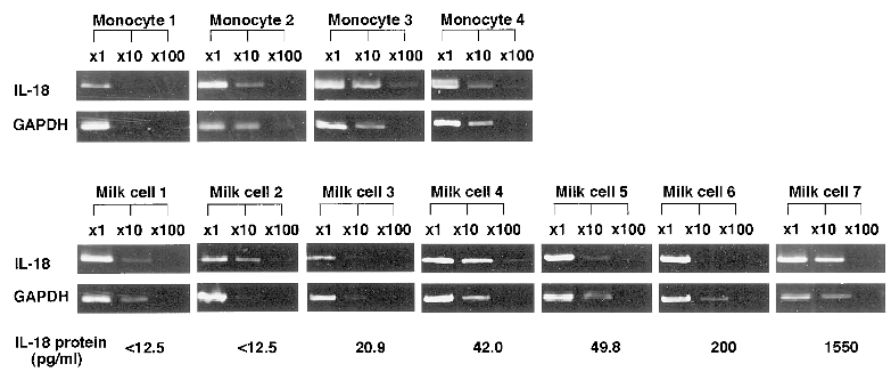

Figure 3. IL-18 mRNA levels in milk cells. IL-18 mRNA levels of milk cells were compared with peripheral blood monocytes from healthy controls. PCR was performed on 10-fold serially diluted samples of cDNA for the comparison of IL-18 mRNA expression. GAPDH mRNA level was used as an internal control. IL-18 protein concentrations of each human milk sample were also indicated.

with those of purified monocytes of peripheral blood from four healthy controls to determine the contribution of milk cells to the high levels of IL-18 in colostrum. IL-18 mRNA levels in human milk cells showed no clear correlation with IL-18 protein concentrations in human milk or with IL-18 mRNA levels in monocytes of peripheral blood, suggesting that cellular components of colostrum did not always make a major contribution to IL-18 levels in colostrum (Fig. 3).

Immunohistochemical identification of IL-18 in mammary gland epithelial cells. Two of seven samples in lactating mammary gland were positive for IL-18 by immunohisto- 
A

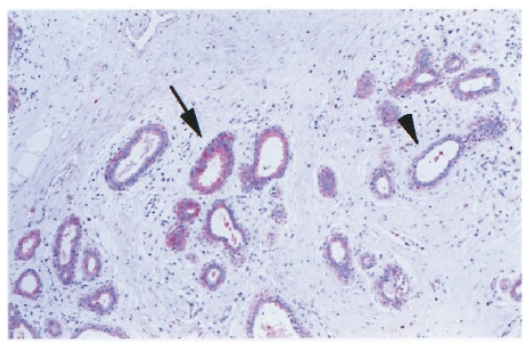

B

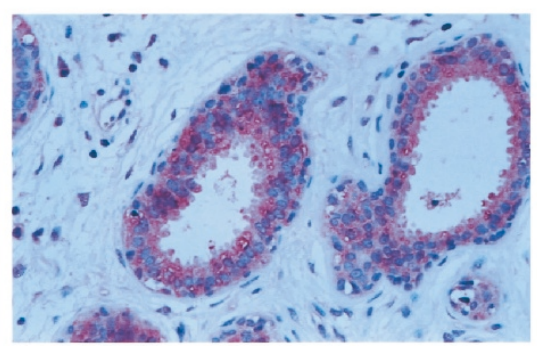

C

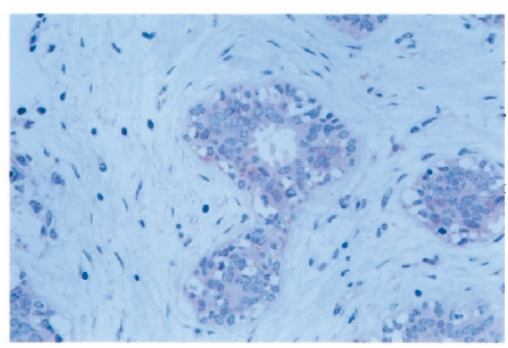

Figure 4. Immunohistochemical staining of IL-18 in mammary gland. (A) IL-18 was detected in lactating mammary gland epithelial cells with active secretion (arrow) but not in those with inactive secretion (arrow head) ( $\times 50$ original magnification). (B) IL-18 producing epithelial cells of lactating mammary gland $(\times 100$ original magnification). (C) IL-18 nonproducing epithelial cells of nonlactating mammary gland $(\times 100$ original magnification).

chemical staining (Fig. 4, $A$ and $B$ ). However, IL-18 was not detected in nonlactating mammary gland (Fig. $4 C$ ).

\section{DISCUSSION}

Th2 dominance in local maternal uterine environment persists during pregnancy, whereas Th1 dominance occurs during abortion-prone pregnancy (23-25). The present finding that the production of IL-18, one of the Th1-inducing cytokines, in human milk was associated with maternal pregnancy complications leading to termination of pregnancy suggested that there might be a common pathophysiology between these two. Pregnancy complications include those with infectious and noninfectious causes; the former was actually associated with an increase in Th1 cytokines in some cases (26). Noninfectious as well as infectious complications affect the production of hormones such as progesterone and $\beta$-estradiol, which suppress Th1 response and enhance Th2 reaction (27). In addition, a recent report has shown that preeclampsia induced Th1 cytokine production $(28,29)$. Thus, it is possible that even noninfectious complications affect local cytokine balance directly or through hormones, especially at the hormone-target organs such as uterus and mammary gland.

Although protective roles of IL-18 are suggested in some bacterial $(30,31)$ and viral infections $(32)$, physiologic and pathologic roles of IL-18 in vivo have not been fully investigated. The functional significance of cytokines in breast milk for neonates was demonstrated by experiments in newborn mice disrupted for TGF- $\beta 1$ gene, showing that they were rescued by milk TGF- $\beta 1$ to survive and develop normally (33), although in humans, there is no direct evidence that the cytokines in milk affect the recipient infants. In humans, breast-fed infants showed efficient protection during lactation against several different forms of infections (34-39), higher proliferative response against purified protein derivative (40), and higher IFN- $\gamma$ production when vaccinated against measles-mumps-rubella (41). Thus, it is possible that IL-18 in colostrum plays important roles in the induction of systemic Th1 response as well as in the local host defense in neonates.

In addition, it is likely that IL-18 in colostrum affects its cellular components. IL-18, in the presence of IL-12, effec- tively elicits macrophage activation, which provides local host defense by inducing the production of other inflammatory cytokines (42), and more directly, by enhancing phagocytosis and intracellular killing of microorganisms. IL-18 may be one of the cytokines, such as TNF- $\alpha$, monocyte chemoattractant protein-1, and RANTES (regulated upon activation, normal $\mathrm{T}$ cell expressed and secreted), that plays a role in inducing activation and differentiation of $\mathrm{T}$ cells, which account for $4 \%$ of milk leukocytes and bear CD45RO antigen $(43,44)$. The presence of radiolabeled milk lymphocytes was demonstrated in the intestinal mucosa (45) and mesenteric lymph nodes of neonatal rats and lambs (46). Maternal $\mathrm{T}$ cells, which had been primed by antigens of microorganisms in maternal intestine, further differentiated to Th1 cells by IL-18 in colostrum, may provide cellular immunity in neonates (47).

IL-18 seems to be produced or secreted mainly by epithelial cells of lactating mammary gland (Fig. 4), similar to macrophage colony-stimulating factor reported previously (48), although it might be partially produced by cellular components of human milk. The significant correlations between the IL-18 and sFasL levels suggested the possibilities that 1) these cytokines were derived from the same origin, 2) IL-18 induced sFasL production by other cells in colostrum (4), and 3) sFasL enhanced IL-18 production by activated macrophages, as Tsutsui et al. (49) reported that IL-18 was induced in macrophages with the stimulation with sFasL. In addition, it is possible that the effect of IL-18 in human milk could be enhanced in the presence of IL-12 and sFasL (4).

These results suggested that human milk contained various cytokines in the context of complicated network. Thus, IL-18, through the interaction with other cytokines in human milk, might offer immunologic signal for the host defense against microorganisms through $\mathrm{NK}$ cell and macrophage activation as well as Th1 cytokine induction in high-risk neonates.

Acknowledgments. The authors thank Dr. Naoko Kinukawa, Department of Medical Informatics, Graduate School of Medical Sciences, Kyushu University, for statistical analyses. 


\section{REFERENCES}

1. Okamura H, Tsutsui H, Komatsu T, Yutsudo M, Hakura A, Tanimoto T, Torigoe K, Okura T, Nukada Y, Hattori K, Akita K, Namba M, Tanabe F, Konishi K, Fukuda S, Kurimoto M 1995 Cloning of a new cytokine that induces IFN-gamma production by T cells. Nature 378:88-91

2. Stoll S, Muller G, Kurimoto M, Saloga J, Tanimoto T, Yamauchi H, Okamura H, Knop J, Enk AH 1997 Production of IL-18 (IFN-gamma-inducing factor) messenger RNA and functional protein by murine keratinocytes. J Immunol 159:298-302

3. Takeuchi M, Nishizaki Y, Sano O, Ohta T, Ikeda M, Kurimoto M 1997 Immunohistochemical and immune-electron-microscopic detection of interferon- $\gamma$-inducing factor (interleukin-18) in mouse intestinal epithelial cells. Cell Tissue Res 289:499-503

4. Okamura H, Tsutsui H, Kashiwamura S, Yoshimoto T, Nakanishi K 1998 Interleukin18: a novel cytokine that augments both innate and acquired immunity. Adv Immunol 70:281-312

5. Kohno K, Kataoka J, Ohtsuki T, Suemoto Y, Okamoto I, Usui M, Ikeda M, Kurimoto M 1997 IFN- $\gamma$-inducing factor (IGIF) is a costimulatory factor on the activation of Th1 but not Th2 cells and exerts its effect independently of IL-12. J Immunol 158:1541-1550

6. Ohtsuki T, Micallef MJ, Kohno K, Tanimoto T, Ikeda M, Kurimoto M 1997 Interleukin 18 enhances Fas ligand expression and induces apoptosis in Fasexpressing human myelomonocytic KG-1 cells. Anticancer Res 17:3253-3258

7. Dao T, Ohashi K, Kayano T, Kurimoto M, Okamura H 1996 Interferon-gammainducing factor, a novel cytokine, enhances Fas ligand- mediated cytotoxicity of murine T helper 1 cells. Cell Immunol 173:230-235

8. Goldman AS, Chedda S, Garofalo R 1997 Spectrum of immunomodulating agents in human milk. Int J Pedia/Oncol 12:664-671

9. Soder O 1987 Isolation of interleukin-1 from human milk. Int Arch Allergy Appl Immunol 83:19-23

10. Saito S, Maruyama M, Kato Y, Moriyama I, Ichijo M 1991 Detection of IL-6 in human milk and its involvement in IgA production. J Reprod Immunol 20:267-276

11. Bryan DL, Hawkes JS, Gibson RA 1999 Interleukin-12 in human milk. Pediatr Res 45:858-859

12. Rudloff HE, Schmalstieg Jr FC, Mushtaha AA, Palkowetz KH, Liu SK, Goldman AS 1992 Tumor necrosis factor-alpha in human milk. Pediatr Res 31:29-33

13. Eglinton BA, Roberton DM, Cummins AG 1994 Phenotype of T cells, their soluble receptor levels, and cytokine profile of human breast milk. Immunol Cell Biol 72:306-313

14. Palkowetz KH, Royer CL, Garofalo R, Rudloff HE, Schmalstieg Jr FC, Goldman AS 1994 Production of interleukin-6 and interleukin- 8 by human mammary gland epithelial cells. J Reprod Immunol 26:57-64

15. Garofalo R, Chheda S, Mei F, Palkowetz KH, Rudloff HE, Schmalstieg FC, Rassin DK, Goldman AS 1995 Interleukin-10 in human milk. Pediatr Res 37:444-449

16. Saito S, Yoshida M, Ichijo M, Ishizaka S, Tsujii T 1993 Transforming growth factor-beta (TGF-beta) in human milk. Clin Exp Immunol 94:220-224

17. Srivastava MD, Srivastava BI 1999 Soluble Fas and soluble Fas ligand proteins in human milk: possible significance in the development of immunological tolerance. Scand J Immunol 49:51-54

18. Sone S, Tsutsumi H, Takeuchi R, Matsuda K, Imai S, Ogra PL, Chiba S 1997 Enhanced cytokine production by milk macrophages following infection with respiratory syncytial virus. J Leukoc Biol 61:630-636

19. Ishizaka S, Kimoto M, Kanda S, Saito S 1998 Augmentation of natural killer cell activity in mice by oral administration of transforming growth factor-beta. Immunology $95: 460-465$

20. Xanthou M, Bines J, Walker WA 1995 Human milk and intestinal host defense in newborns: an update. Adv Pediatr 42:171-208

21. Akita K, Ohtsuki T, Nukada Y, Tanimoto T, Namba M, Okura T, TakakuraYamamoto R, Torigoe K, Gu Y, Su MSS, Fujii M, Satoh-Itoh M, Yamamoto K, Kohno K, Ikeda M, Kurimoto M 1997 Involvement of caspase-1 and caspase-3 in the production and processing of mature human interleukin 18 in monocytic THP. 1 cells. J Biol Chem 272:26595-26603

22. Draper NR, Smith H 1981 Applied Regression Analysis, 2nd Ed. John Wiley \& Sons, New York, pp 307-311

23. Wegmann TG, Lin H, Guilbert L, Mosmann TR 1993 Bidirectional cytokine interactions in the maternal-fetal relationship: is successful pregnancy a TH2 phenomenon? Immunol Today 14:353-356
24. Raghupathy R, Makhseed M, Azizieh F, Hassan N, Al-Azemi M, Al-Shamali E 1999 Maternal Th1- and Th2-type reactivity to placental antigens in normal human pregnancy and unexplained recurrent spontaneous abortions. Cell Immunol 196:122130

25. Raghupathy R 1997 Th1-type immunity is incompatible with successful pregnancy. Immunol Today 18:478-482

26. Santhanam U, Avila C, Romero R, Viguet H, Ida N, Sakurai S, Sehgal PB 1991 Cytokines in normal and abnormal parturition: elevated amniotic fluid interleukin-6 levels in women with premature rupture of membranes associated with intrauterine infection. Cytokine 3:155-163

27. Dealtry GB, O'Farrell MK, Fernandez N 2000 The Th2 cytokine environment of the placenta. Int Arch Allergy Immunol 123:107-119

28. Sacks G, Sargent I, Redman C 1999 An innate view of human pregnancy. Immunol Today 20:114-118

29. Saito S, Umekage H, Sakamoto Y, Sakai M, Tanebe K, Sasaki Y, Morikawa H 1999 Increased T-helper-1-type immunity and decreased T-helper-2-type immunity in patients with preeclampsia. Am J Reprod Immunol 41:297-306

30. Garcia VE, Uyemura K, Sieling PA, Ochoa MT, Morita CT, Okamura H, Kurimoto M, Rea TH, Modlin RL 1999 IL-18 promotes type 1 cytokine production from NK cells and $\mathrm{T}$ cells in human intracellular infection. J Immunol 162:6114-6121

31. Fassbender K, Mielke O, Bertsch T, Muehlhauser F, Hennerici M, Kurimoto M, Rossol S 1999 Interferon-gamma-inducing factor (IL-18) and interferon-gamma in inflammatory CNS diseases. Neurology 53:1104-1106

32. Sareneva T, Matikainen S, Kurimoto M, Julkunen I 1998 Influenza A virus-induced IFN-alpha/beta and IL-18 synergistically enhance IFN-gamma gene expression in human T cells. J Immunol 160:6032-6038

33. Letterio JJ, Geiser AG, Kulkarni AB, Roche NS, Sporn MB, Roberts AB 1994 Maternal rescue of transforming growth factor- $\beta 1$ null mice. Science 264:1936-1938

34. Saarinen UM 1982 Prolonged breast feeding as prophylaxis for recurrent otitis media. Acta Pediatr Scand 71:567-571

35. Marild S, Jodal U, Hanson LA 1990 Breastfeeding and urinary-tract infection. Lancet 336:942

36. Ashraf RN, Jalil F, Zaman S, Karlberg J, Khan SR, Lindblad BS, Hanson LA 1991 Breastfeeding and protection against neonatal sepsis in a high risk population. Arch Dis Child 66:488-490

37. Wright AL, Holberg CJ, Martinez FD, Morgan WJ, Taussig LM 1989 Breast-feeding and lower respiratory tract illness in the first year of life. BMJ 299:946

38. Bhan MK, Bhandari N 1996 Epidemiology and management of persistent diarrhea in children of developing countries. Indian J Med Res 104:103-114

39. Scariati PD, Grummer-Strawn LM, Fein SB 1997 A longitudinal analysis of infant morbidity and breast feeding in the United States. Pediatrics 99:E5

40. Papst HG, Godel J, Grace M, Cho H, Spady DW 1989 Effect of breast-feeding on immune response to BCG vaccination. Lancet 1:295-297

41. Pabst HF, Spady DW, Pilarski LM, Carson MM, Beeler JA, Krezolek MP 1997 Differential modulation of the immune response by breast or formula feeding of infants. Acta Paediatr 86:1291-1297

42. Munder M, Mallo M, Eichmann K, Modolell M 1998 Murine macrophages secrete interferon gamma upon combined stimulation with interleukin (IL)-12 and IL-18: a novel pathway of autocrine macrophage activation. J Exp Med 187:2103-2108

43. Wirt DP, Adkins LT, Palkowetz KH, Schmalstieg FC, Goldman AS 1992 Activated and memory T lymphocytes in human milk. Cytometry 13:282-290

44. Bertotto A, Gerli R, Fabietti G, Crupi S, Areangeli C, Scalise F, Vaccaro R 1990 Human breast milk $\mathrm{T}$ lymphocytes display the phenotype and functional characteristics of memory T cells. Eur J Immunol 20:1877-1880

45. Weiler IJ, Hickler W, Sprenger R 1983 Demonstration that milk cells invade the suckling neonatal mouse. Am J Reprod Immunol 4:95-98

46. Sheldrake RF, Husband AJ 1985 Intestinal uptake of intact maternal lymphocytes by neonatal rats and lambs. Res Vet Sci 39:10-15

47. Bernt KM, Walker WA 1999 Human milk as a carrier of biochemical messages. Acta Paediatr 430:27-41

48. Hara T, Irie K, Saito S, Ichijo M, Yamada N, Yanai N, Miyazaki S 1995 Identification of macrophage colony-stimulating factor in human milk and mammary gland epithelial cells. Pediatr Res 37:437-443

49. Tsutsui H, Kayagaki N, Kuida K, Nakano H, Hayashi N, Takeda K, Matsui K, Kashiwamura S, Hada T, Akira S, Yagita H, Okamura H, Nakanishi K 1999 Caspase-1-independent, Fas/Fas ligand-mediated IL-18 secretion from macrophages causes acute liver injury in mice. Immunity 11:359-367 